\title{
LOAD - DISPLACEMENT BEHAVIOUR OF A PILE ON A SLOPING GROUND FOR VARIOUS L/D RATIOS
}

\author{
SIVAPRIYA S. V. ${ }^{*}$, Rahul RAMANATHAN ${ }^{2}$
}

\begin{abstract}
An experimental study was carried out to understand the behaviour of a laterally loaded single pile on a slope with different length/diameter (L/D) ratios driven into cohesionless soil for a relative density of $70 \%$. Static loading was applied in both forward and reverse directions for slopes of $1 \mathrm{~V}: 1.5 \mathrm{H}, 1 \mathrm{~V}: 2 \mathrm{H}$, and $1 \mathrm{~V}: 2.5 \mathrm{H}$ for a constant $\mathrm{L} / \mathrm{D}$ ratio representing flexible pile behaviour. It was observed that the load ratio (load on a sandy slope to the horizontal ground) decreased with an increase in the slope's angle. The post-static behaviour of the pile under the same conditions was also studied to evaluate the elastic displacement, which increased with an increase in the slope's angle. Due to the constant passive resistance under the reverse loading, the lateral load on the slope's crest was almost equal to the horizontal ground's condition. The effect of the $L / D$ ratio was studied by varying the length and diameter and by maintaining the other parameter as a constant. The lateral load of a pile increased with an increase in its length and diameter.
\end{abstract}

\section{Address}

1 Dept. of Civil Engineering, SSN College of Engineering, Kalavakkam, Chennai, India

* Corresponding author: sivapriyavijay@gmail.com

\section{Key words}

- Laterally loaded single pile,

- cohesionless soil,

- active slope,

- length to diameter ratio,

- stiffness factor.

\section{INTRODUCTION}

Pile foundations are subjected to axial and lateral loads or a combination of both loads. In offshore berthing structures and railway embankments, pile foundations are subjected to lateral loads from wind, waves and currents, and surcharge loads. These loads must be in an equilibrium with the reaction of the soil, which is mobilized when the foundation pile starts to deflect due to the lateral forces. The study of a laterally-loaded pile's response requires a proper assessment of the soil - structure interaction phenomena involving the interaction between the pile and the surrounding soil. Calculating the ultimate lateral resistance of a pile on horizontal ground has been widely discussed by many researchers (Brinch,1961; Brom, 1964; Reese et al., 1974; Poulos and Davis, 1980; Briaud and Smith,1983; Meyerhof et al., 1988; Fleming et al., 1992; and McVay et al.,1995). McClelland and Focht (1956) developed a classic p-y curve method to understand soil resistance upon lateral loading at any depth.
The behaviour of a pile on a slope, which can either be a natural or man-made slope, has a different behaviour than its behaviour on horizontal ground. It is understood from the literature that the failure mode of a pile depends on the relative stiffness of the pile-soil system. Poulos (1976) ascribed importance to the stiffness of a pile on a slope and provided a chart to find the ultimate lateral load of a flexible pile. When a pile is installed on a sloping ground and subjected to a lateral load, the expected failure wedges on either side are different from those on the horizontal ground.

Much of the literature has dealt with the effect of a slope when moved away from a slope's crest. Terashi et al., 1991, observed that the effect of a slope became ineffective if the pile was placed at an approximate distance of $2.5 \mathrm{D}$ (D : diameter of the pile) away from the crest of the slope on horizontal ground. The maximum limiting distance of a pile away from a slope was 20D (Bouafia and Bouguerra, 1996), and the minimum was 4D (Barker, 2012). Mirzoyan (2007) reported that there was no effect on a pile due to active pressure on partially saturated soil. A laboratory experiment conducted 
by Muthukkumaran (2004) showed the effect of relative density on a pile's deflection. Factors influencing the ultimate resistance were the properties of the soil, the confining pressure, the embedded depth, and the slope's angle. The displacement of the pile increased with an increase in the ground slope to a certain depth, and the maximum bending moment increased with an increase in the slope and the L/D ratio, where $\mathrm{L}$ - the embedded length of the pile (Sawant and Shukla, 2012). The reduction in the capacity of a pile increased when the pile was moved towards a slope from the crest to the $2 R$ ( $R$ - relative stiffness factor for cohesive soil) position of the slope by $10-50 \%$, depending upon the slope's angle compared to the horizontal ground's condition (Sivapriya and Gandhi, 2013). The lateral loading of a pile on sloping ground in a downslope direction resulted in a reduction in $\mathrm{Pu}$, with not much effect on the stiffness of the $\mathrm{p}-\mathrm{y}$ curves at a small deflection, while the bending moment of a pile increased with an increase in the slope's steepness (Muthukkumaran and Begum, 2015).

Hence, this study focuses on the lateral load resistance of piles on sloping ground with different $\mathrm{L} / \mathrm{D}$ ratios. The objective of this research is to study the effect of the slope's angle, the length of the pile, the diameter of the pile, and the loading direction on the lateral capacity of piles installed in an active cohesionless soil slope (active slope - a stable slope: DeBeer, 1977) through laboratory experiments.

\section{MATERIAL PROPERTY}

\subsection{Parametric Study}

The main intent of the study is to understand the load-displacement behaviour of a pile subjected to a lateral load located on the crest of a slope under different loading conditions i.e., forward (towards the slope) and in reverse (away from the slope). In addition, the stiffness behaviour of a pile was also studied. Table 1 shows the detailed parameters involved in the laboratory experiments.

Tab. 1 Parametric Study

\begin{tabular}{|l|l|l|l|}
\hline $\begin{array}{l}\text { Ground } \\
\text { Condition }\end{array}$ & $\begin{array}{l}\text { Loading } \\
\text { Condition }\end{array}$ & $\begin{array}{l}\text { Length of the } \\
\text { pile, mm }\end{array}$ & $\begin{array}{l}\text { Diameter of the } \\
\text { pile, mm }\end{array}$ \\
\hline Horizontal & Forward & 500 & 16 \\
\hline \multirow{2}{*}{$1 \mathrm{~V}: 1.5 \mathrm{H}$} & Forward & 500 & 16 \\
\cline { 2 - 4 } & Reverse & 500 & 16 \\
\hline \multirow{2}{*}{$1 \mathrm{~V}: 2 \mathrm{H}$} & Forward & 500 & 16 \\
\cline { 2 - 4 } & Reverse & 500 & 16 \\
\hline \multirow{3}{*}{$1 \mathrm{~V}: 2.5 \mathrm{H}$} & Forward & 500 & 16 \\
\cline { 2 - 4 } & Reverse & 500 & 16 \\
\hline \multirow{3}{*}{$1 \mathrm{~V}: 2 \mathrm{H}$} & \multirow{3}{*}{ Forward } & 192 & 16 \\
\cline { 3 - 4 } & & 288 & 16 \\
\hline \multirow{3}{*}{$1 \mathrm{~V}: 2 \mathrm{H}$} & \multirow{3}{*}{ Forward } & 384 & 16 \\
\hline & & 300 & 25 \\
\hline & & 300 & 16 \\
\hline
\end{tabular}

\subsection{Soil}

Sand obtained from rivers located in Thiruporur, Chennai, India, was used as the sample for the experiments. Table 2 shows the properties of soil evaluated as per the relevant Indian standards (IS). The co-efficient of the curvature $\left(\mathrm{C}_{\mathrm{c}}\right)$ and the co-efficient of uniformity $\left(\mathrm{C}_{\mathrm{u}}\right)$ were calculated using Equations 1 and 2:

$$
\begin{gathered}
C_{u}=\frac{D_{60}}{D_{10}} \\
C_{c}=\frac{D_{30}^{2}}{D_{60} D_{10}}
\end{gathered}
$$

Whereas, $\mathrm{D}_{10}$ is the effective mean size of the particle; $\mathrm{D}_{50}$ is the average particle size. The co-efficient of the subgrade modulus of the soil is $7.5 \mathrm{MN} / \mathrm{m}^{3}$ as per Terzaghi, 1955 .

Tab. 2 Properties of the soil

\begin{tabular}{|c|c|c|c|c|c|}
\hline Property & Relevant IS Code & \multicolumn{4}{|c|}{ Values } \\
\hline $\begin{array}{c}\text { Specific } \\
\text { Gravity }\left(\mathrm{G}_{\mathrm{s}}\right)\end{array}$ & $2720-$ Part III & \multicolumn{4}{|c|}{2.75} \\
\hline $\begin{array}{c}\text { Grain Size } \\
\text { Distribution } \\
\text { (Fig. 1) }\end{array}$ & $2720-$ Part IV & $\mathrm{D}_{10}, \mathrm{~mm}$ & $\mathrm{D}_{50}, \mathrm{~mm}$ & $\mathrm{Cu}$ & $\mathrm{Cc}$ \\
\cline { 3 - 6 } & 0.34 & 0.74 & 2.176 & 0.878 \\
\hline $\begin{array}{c}\text { Shear } \\
\text { Strength, deg }\end{array}$ & $2720-$ Part XIII & \multicolumn{4}{|c|}{32} \\
\hline $\begin{array}{c}\text { Relative } \\
\text { Density, \% }\end{array}$ & $2720-$ Part XIV & \multicolumn{4}{|c|}{70} \\
\hline $\begin{array}{c}\text { IS } \\
\text { Classification }\end{array}$ & 1498 & \multicolumn{3}{|c|}{ Poorly Graded Sand (SP) } \\
\hline
\end{tabular}

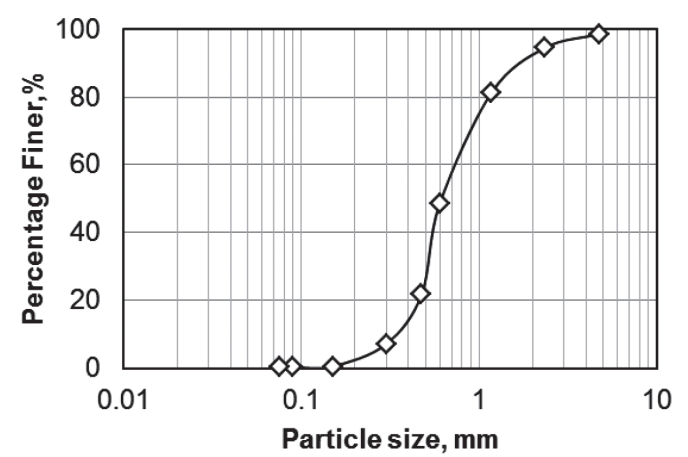

Fig. 1 Particle size gradation

\subsection{Pile}

The dimensions of the model test pile were determined using the Buckingham $\pi$ theorem; a dimensionless analysis and a scale of 1:20 were used for determining the dimensions of the pile. The model test pile had an outer diameter of $16 \mathrm{~mm}$ and an inner diameter of $14 \mathrm{~mm}$; it was $500 \mathrm{~mm}$ long with a plugged bottom. The flexural stiffness (EI) of the material was found to be $91.85 \times 10^{6} \mathrm{~N} \cdot \mathrm{mm}^{2}$.

\subsection{Placement of the Sand}

The soil was filled in a tank with a relative density of $70 \%$ with the height of a fall of $25 \mathrm{~cm}$ that represented the dense nature of the soil by means of a hopper and cone arrangement (Fig. 2). This arrangement contained a hopper connected to a $940 \mathrm{~mm}$ - long pipe and an inverted cone at the bottom. The hopper had a holding capacity of about $4.29 \mathrm{~kg}$ of sand. The sand passed through a $24.8 \mathrm{~mm}$ inter- 


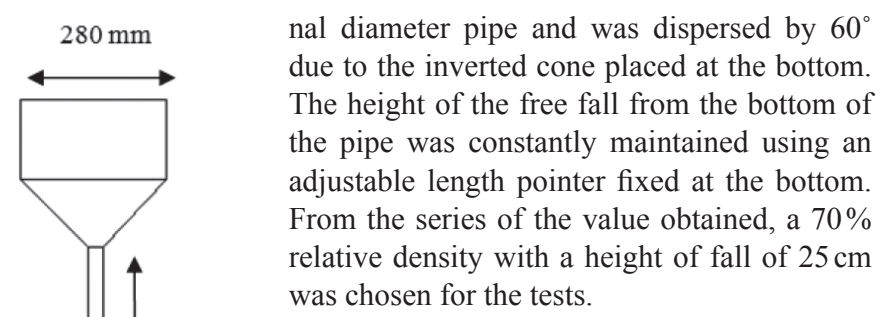
have a size of $8-12 \mathrm{D}$ and $3-4 \mathrm{D}$ in the direction of and perpendicular to the lateral loading to have a zero side wall effect. A fabricated tank with a depth of $1 \mathrm{~m} \times 1 \mathrm{~m} \times 0.5 \mathrm{~m}$ was used (Fig. 3 ); with a width of $1 \mathrm{~m}$, it was clear that the tank was free from a sidewall effect. Three sides of the tank were made of steel with toughened glass on one side, and a grid was marked on the glass to ensure the formation of the desired slope. The loads were applied as dead loads through a pulley arrangement by means of high-tension wire, and the displacement was observed through

Fig. 2 Cone Set-up a dial gauge fixed on the pile head.

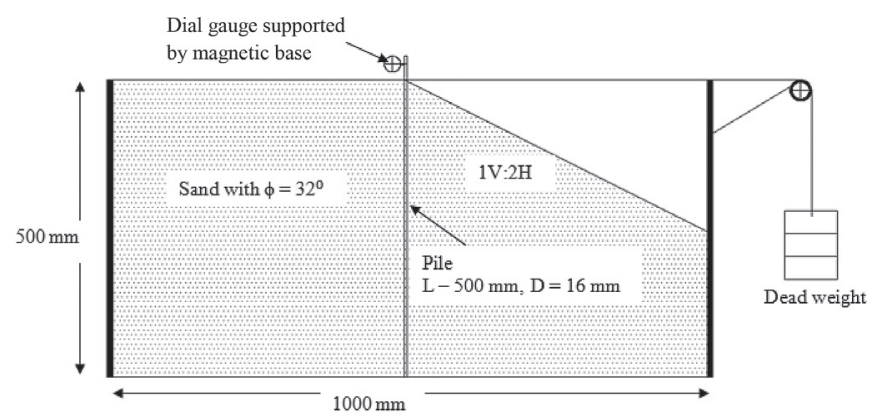

Fig. 3 Test Tank Details

\subsection{Experimental Methodology}

The ultimate lateral loads were calculated as per the following conditions:

i. Brom's, 1964 - The lateral load was taken as the load corresponding to a displacement equal to $20 \%$ of the pile's diameter.

ii. Meyerhof et al.,1981 - The ultimate lateral capacity occurred when the portion of the load-deflection curve became straight.

iii. IS 2911 (Part IV) - The lateral load corresponded to a $5 \mathrm{~mm}$ displacement

In this study, Brom's method, which is widely used for estimating the ultimate lateral capacity, was taken into consideration. The loads were added at an increment of $10 \%$, and the corresponding displacement reading was observed after every 30 minutes (Meyerhof,1981). Upon filling the tank for the desired slope, the loading for the pile on the slope was initiated.

Once the displacement reached $0.2 \mathrm{D}$, the test was terminated, and the post-static loading behaviour of the pile was studied by means of removing the load in the same sequence as that of the loading condition. The studies also involved the behaviour of the static lateral load of the pile towards and against the slope.
The initial test was carried out by filling the tank with zero slopes with a $70 \%$ relative density. To understand the effect of the stiffness in a lateral load capacity, various $\mathrm{L}$ and $\mathrm{D}$ were used. For determining the flexibility of the pile, the stiffness factor ' $\mathrm{T}$ ' was found using Equation 3, and the value was $113 \mathrm{~mm}$.

$$
y=A_{y} \frac{H T^{3}}{E I}
$$

Where, y- displacement, A deflection factor (2.42), H - horizontal load, T - stiffness factor, and EI was the flexural stiffness factor.

By calculating the stiffness factor, the flexibility of the pile can be determined as per Poulos and Hull, 1989, and the conditions are listed below:

i. $\quad \mathrm{L} / \mathrm{D}<12$ - short pile; for which $\mathrm{L}<2 \mathrm{~T}$ (T- stiffness factor)

ii. $\mathrm{L} / \mathrm{D}>24-$ long pile, for which $\mathrm{L}>4 \mathrm{~T}$

iii. $\mathrm{L} / \mathrm{D}-12$ and 24 were termed as intermediate piles

\section{RESULTS AND DISCUSSION}

Initially, the test was conducted by placing the pile on a horizontal ground condition, and the ultimate lateral load was observed as $64.5 \mathrm{~N}$ for a $3.2 \mathrm{~mm}$ displacement; this value was taken as a reference value for further studies to understand the reduction in capacity. The post - static behaviour of the pile, which showed the elastic displacement of the pile, was observed as being $1.4 \mathrm{~mm}$ (Fig. 4).

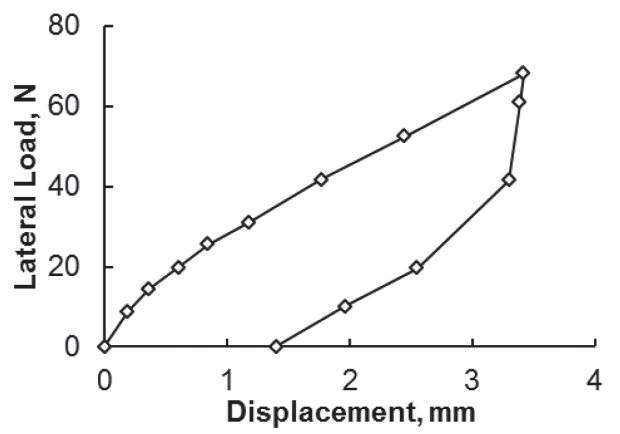

Fig. 4 Load - Deflection curve for horizontal ground

\subsection{Effect of the slope}

Under the forward loading for the three different slopes $1 \mathrm{~V}: 2.5 \mathrm{H}$ $\left(21.8^{0}\right), 1 \mathrm{~V}: 2 \mathrm{H}\left(26^{0}\right)$, and $1 \mathrm{~V}: 1.5 \mathrm{H}\left(33.7^{0}\right)$, the lateral loads were 62.5 $\mathrm{N}, 41 \mathrm{~N}$, and $40 \mathrm{~N}$ respectively (Fig. 5). The reductions in capacity were $3.2 \%, 57.3 \%$, and $61.25 \%$, which were mainly due to the soil reduction in soil volume on the passive side of the slope. The passive resistance contributed in a major way to the ultimate resistance of the pile under a lateral load; the volume was reduced when the slope angle increased from $21.8^{0}$ to $33.7^{\circ}$, which resulted in a reduction in the passive resistance.

The calculated load ratio (load on a sandy slope to horizontal ground) for the three different slopes was plotted in Fig. 6. Due to the larger contribution of the passive wedge formed in front of the pile, the load ratio increased with a decrease in the steepness (slope angle) of the slope, and it became almost constant after a slope of $1 \mathrm{~V}: 2 \mathrm{H}\left(26^{0}\right)$.

After the calculations of the ultimate resistance under the forward loading post, the static behaviour of the pile was studied by unloading it, and the elastic behaviour was observed. The elastic displacement 


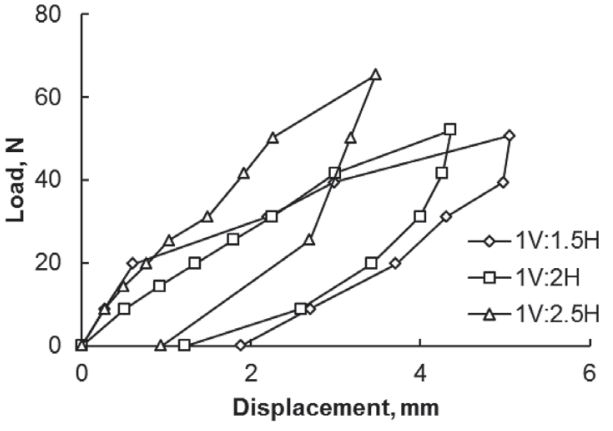

Fig. 5 Effect of slope in ultimate load-forward loading

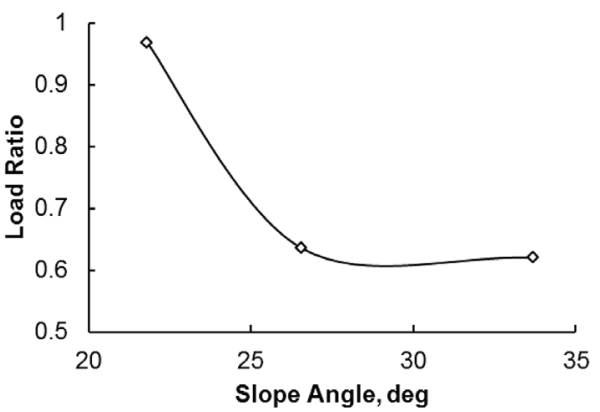

Fig. 6 Load Ratio for the different slope angles

was due to the elastic recovery of the pile material and yielded soil in front of the pile. When the load was removed step-by-step, which is called "post-static loading" for the different conditions, the elastic displacement was noted. It can be seen in Figure 5 that the elastic displacement increases with an increase in the slope's angle.

The behaviour of the piles when subjected to reverse lateral loading on all the slopes was similar to the behaviour of the pile on the horizontal ground. The capacity of the pile under reverse loading was almost similar to that of the horizontal load with a minimal reduction in capacity. This proved that the passive resistance of the soil affected the deflection of the pile more than the active load of the soil. The lateral capacity of the pile was greater when the pile was loaded laterally in the reverse direction when compared to the pile loaded laterally in the forward direction. In addition, the restoration capacity of the pile was greater for the pile loaded laterally in the reverse direction compared to the pile loaded laterally in the forward direction. In the post-static behaviour, the elastic displacement increased with an increase in the slope's angle (Fig. 7).

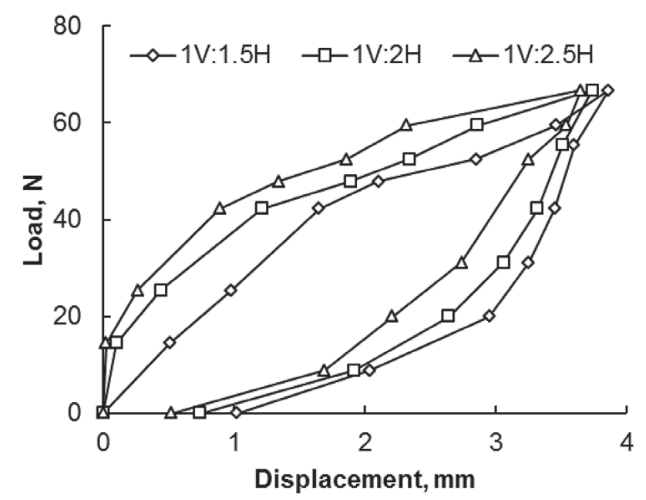

Fig. 7 Effect of reverse loading behaviour

\subsection{Effect of relative stiffness on the lateral load}

\subsubsection{Effect of the pile's length}

By varying the length of the pile and maintaining the diameter as constant on the $1 \mathrm{~V}: 2 \mathrm{H}$ slope, when the pile was placed on a slope crest under forward loading, the ultimate resistance of the pile was studied. Varied lengths of the pile were $192 \mathrm{~mm}, 288 \mathrm{~mm}$ and $384 \mathrm{~mm}$, which depicted small, intermediate and long pile behaviour respectively with a constant diameter of $16 \mathrm{~mm}$ (Fig. 8). With an increase in the L/D ratio, i.e., transforming the behaviour from rigid to flexible, the load-bearing capacity increased, which was mainly due to the stiffness of the pile. Back-calculating the stiffness factor using equation 1 for the known load and its corresponding displacement showed the main reason for the reduction. Figure 9 showed the reduction is linear through $\mathrm{R}^{2}$, which is $0.967(=1)$. The post - static behaviour showed the elastic recovery was greater for the long pile with a displacement of $2.5 \mathrm{~mm}$, whereas for the intermediate and short piles, it was $3.6 \mathrm{~mm}$ and $4.4 \mathrm{~mm}$ respectively.

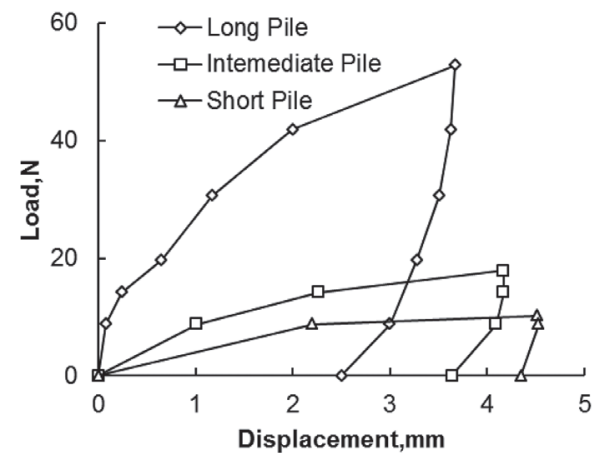

Fig. 8 Effect of length on lateral load behaviour

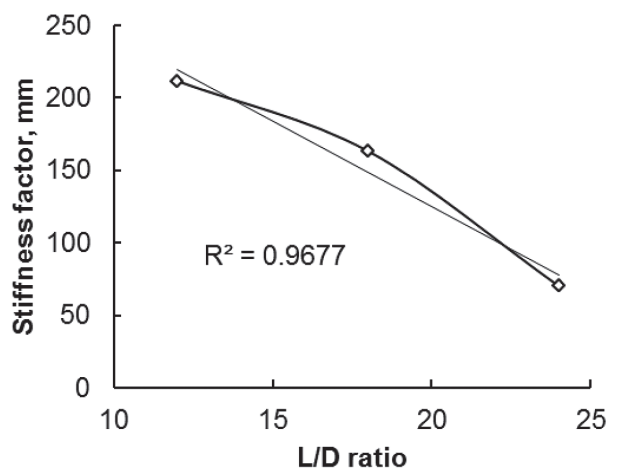

Fig. 9 Effect of lateral load on stiffness factor for varied lengths under a constant diameter

\subsubsection{Effect of the pile's diameter}

The effect of the diameter also affects the behaviour of laterally loaded piles. Piles with varied diameters of $25 \mathrm{~mm}, 16 \mathrm{~mm}$, and $12.5 \mathrm{~mm}$, but with a constant length of $300 \mathrm{~mm}$, and which showcased short, intermediate and long piles, were used. As the diameters were the criteria for finding the ultimate lateral resistance of the pile, loads corresponding to $5 \mathrm{~mm}, 3.2 \mathrm{~mm}$ and $2.5 \mathrm{~mm}$ were noted. For the varying $\mathrm{L} / \mathrm{D}$ ratios, the lateral capacity was high for the larger diameter pile (Fig. 10). However, the elastic recovery 


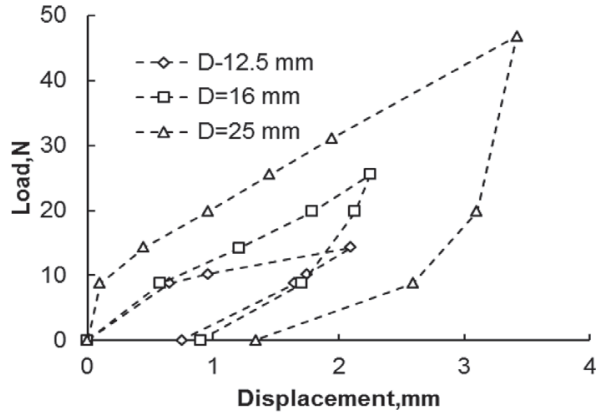

Fig. 10 Effect of diameter on the lateral load behaviour

value was high for the smaller diameter pile with the lowest value of $0.75 \mathrm{~mm}$.

The pile's diameter versus the length played a vital role in calculating the lateral resistance. As the confining pressure offered to the pile by the soil is high for a large cross-sectional area and because of the stiffness of the soil, a large diameter pile can hold a larger lateral load. The short rigid pile with a larger diameter showed a high ultimate bearing capacity in spite of its rigid behaviour. This was also observed with a decrease in the diameter of the pile under a constant length; the stiffness factor increased till $\mathrm{L} / \mathrm{D}=18$ represented the intermediate pile but decreased beyond it (Fig.11).

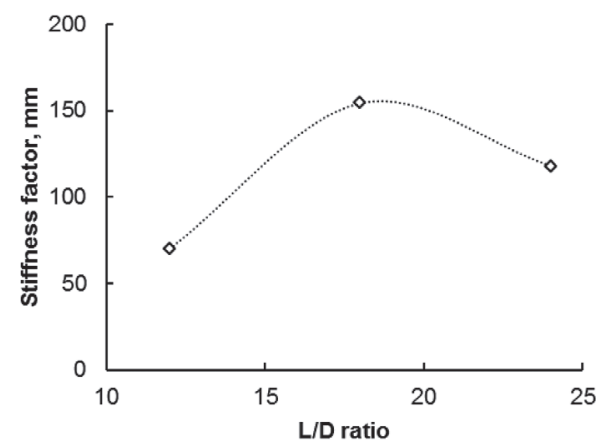

Fig.11 Effect of a lateral load on stiffness for varied diameters with a constant length

\section{COMPARATIVE STUDY}

A comparative study was done for the various slope angles and load ratios from previous work (Fig. 12). The pile was placed on a slope's crest for three different slopes $(1 \mathrm{~V}: 1.5 \mathrm{H}, 1 \mathrm{~V}: 2 \mathrm{H}$ and $1 \mathrm{~V}: 2.5 \mathrm{H})$ in sandy soil and compared with the work of Chen and Martin, 2001; Chae et al. 2004; Mezazigh and Levacher, 1998; and Muthukkumaran and Almas Begum, 2015.

The load ratio is defined as the ratio of the ultimate load on a slope and on horizontal ground under similar conditions. For steeper slopes, the value compared well with the previous work; but for the flatter slopes $(1 \mathrm{~V}: 2.5 \mathrm{H})$, there were huge variations due to the change in relative density, which was not normalised.

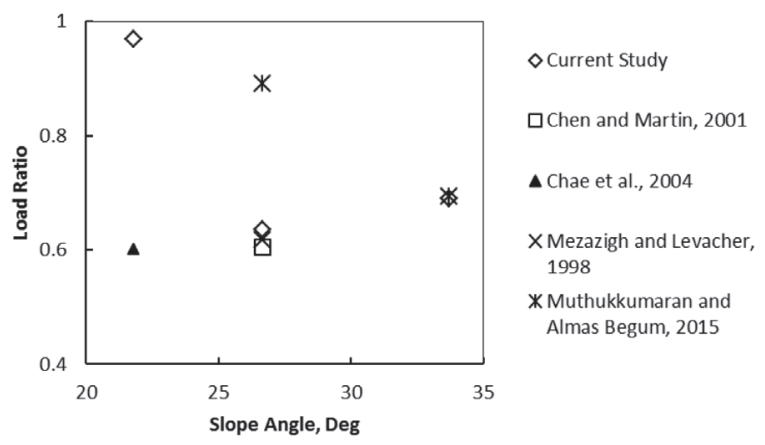

Fig. 12 Comparative study

\section{CONCLUSION}

Laboratory tests were done for varying diameters, lengths and slopes, and the following observations were made for laterally loaded piles on a slope. There was a reduction in capacity when the ground was shifted from horizontal to sloping due to the resisting volume of a passive wedge. It was much smaller for sloping ground with forward loading when compared to horizontal ground. While loading a pile towards an embankment, there is not much of a change in its capacity; it behaves similarly to that of the horizontal ground's conditions. The effect of the diameter is high in the lateral load capacity compared to that of the length, as the inertial force is larger for a larger diameter pile, which is similar to the study of Chandaluri and Sawant, 2016.

\section{Acknowledgement}

The authors would like to thank the management of the SSN College of Engineering for providing the funds to conduct the tests in the laboratory. 


\section{REFERENCES}

Barker, P. D. (2012) Effects of soil slope on the lateral capacity of piles in cohesionless soils. M.S. thesis, Oregon State University, Corvallis, U.S.A.

Bouafia, A - Bouguerra A. (1996) Centrifuge testing of the behaviour of a horizontally loaded flexible pile near to a slope. International Journal of Rock Mechanics and Mining Sciences and Geomechanics, Vol. 33, No. 3, p.135.

Briaud, J - Smith, T. D. (1983) Using the pressuremeter curve to design laterally loaded piles. Proceedings of 15 th Offshore Technology Conference, p. 495-502.

Brinch Hansen, J. (1961) The ultimate resistance of rigid piles against transversal forces. Bulletin No. 12, Danish Geotechnical Institute, Denmark, p. 5-9.

Broms, B. (1964) Lateral resistance of piles in cohesionless soils. Journal of Soil Mechanics and Foundation Division, Vol. 90, No. 2, p. 123-156.

Chae, K. S. - Ugai, K. - Wakai, A. (2004) Lateral resistance of short single piles and pile groups located near slopes. International Journal of Geomechanics,Vol. 2, No. 2, p. 93-104.

Chandaluri V. K - Sawant V. A. (2016) Effect of slope angle on pile response. Indian Journal Of Science And Technology. Vol. 9, No. 48, p. 1-6 DoI: 10.17485/ijst/2016/v9i48/105300.

Chen, C. Y. - Martin, G. R. (2001) Effect of Embankment Slope on Lateral Response of Piles. Proceedings of the 2nd International FLAC Conference, Lyon, Billaux et al. (eds.). A.A. Belkema, Lisse, $p$.47-54.

De Beer, E. E. (1977) Piles subjected to static lateral loads. State of the Art Report. Proceedings of the 9th ICSMFE, 10, Tokyo, p.1-14.

Fleming, W. G. K. - Weltman, A. J. - Randolph, M. F. - Elson, W. K. (1992) Piling Engineering $2^{\text {nd }}$ ed., Halsted Press, New York.

IS: 1498 (1970 - Reaffirmed 2002) Indian Standard classification and identification of soils for general engineering purposes. $\mathrm{Bu}$ reau of Indian Standards, New Delhi.

IS: 2720 - Part III/sec 1 (1980 - reaffirmed 2007) Indian Standard Methods of Tests for Soils - Determination of specific gravity, Bureau of Indian Standards, New Delhi.

IS: 2720 part IV (1985 - reaffirmed 2006) Indian Standard Methods of Tests for Grain Size Analysis. Bureau of Indian Standards, New Delhi.

IS: 2911 part 4 (1985 - reaffirmed 2006) Code of practice for design and construction of pile foundations-Load test on piles. Bureau of Indian Standards, New Delhi.

IS-2720 part XIII (1986 - reaffirmed 2002) Indian Standard Methods of Tests for Soils - Direct Shear Test, Bureau of Indian Standards, New Delhi.

IS-2720 part XIV (1983 - reaffirmed 2006) Indian Standard Methods of Tests for Soils - Determination of relative density, Bureau of Indian Standards, New Delhi.

McClelland, B. - Focht, J. A. (1956) Soil modulus for laterally loaded piles.Transactions of the American Society of Civil Engineers, Vol. 82, No. 4, p.1-22.
McVay, M. - Casper, R. - Shang, T. (1995) Lateral response of threerow groups in loose and dense sands at 3D and 5D pile spacing. Journal of Geotechnical Engineering, ASCE, Vol. 121(5), p.436441.

Meyerhof G. G. - Mathur S. K. - Valsangkar A. J. (1981) Lateral resistance and deflection of rigid wall and piles in layered soils. Can. Geotech. J., Vol.18, p.159-170.

Meyerhof, G. G. - Sastry, V. V. R. N. - Yalcin, A.A. S. (1988) Lateral resistance and deflection of flexible piles. Canadian Geotechnical Journal, Vol. 25, p. 511-522.

Mezazigh, S. - Levacher, D. (1998) Laterally loaded piles in sand: Slope effect on $p$ - y reaction curves.Canadian Geotechnical Journal,Vol. 35, No.3, p. 433-441.

Mirzoyan, A. D. (2007) Lateral resistance of piles at the crest of slopes in sand. M.S. Thesis, Idaho, USA.

Muthukkumaran, K. (2004) Non-Linear soil structure interaction of piles on sloping ground. Ph.D., IIT- Madras, Chennai.

Muthukkumaran, K - Begum, A. (2015) Experimental investigation of single model pile subjected to lateral load in sloping ground. Geotechnical and Geological Engineering, Vol.33, No.4, p. 935-946.

Poulos, H. G. (1976) Behavior of laterally loaded piles near a cut or slope. Australian Geomechanics Journal, Vol.6, No.1, p.6-12.

Poulos, H. - Hull, T.(1989) The role of analytical geomechanics in foundation engineering. Foundation engineering: Current principles and practices, Vol. 2, ASCE, Reston, VA, USA, p.15781606.

Poulos, H. G. - Davis, E. H. (1980) Pile foundation analysis and design. John Wiley and Sons, Inc., New York.

Prakash, S. (1962) Behavior of pile groups subjected to lateral loads. Ph.D. thesis, Univ. of Illinois, Urbana,USA.

Reese, L. C. - Cox, W. R.- Koop, F. D.(1974) Analysis of laterally loaded piles in sand. Proceedings of $6^{\text {th }}$ Offshore Technology Conference, Vol. 2, Offshore Technology Conference, Dallas, p. 473-483.

Sawant, V. A. - Shukla, S. K. (2012) Finite element analysis for laterally loaded piles in sloping ground. Coupled System Mechanics, Vo.1, No.1, p. 59-78. DOI: 10.1007/s40098-012-00226.2012 .

Sivapriya, S. V - Gandhi, S. R. (2013) Experimental and numerical behaviour of single pile subjected to lateral load. Indian Geotechnical Journal, Vol. 43, No.1, p.105-114.

Terashi, M. - Kitazume, M. - Manuyama, A. - Yamamoto, Y. (1991) Lateral resistance of a long pile in or near the slope. Proceedings of Centrifuge '91. H.-Y. Ko. and F. Mclean, eds., Balkema, Rotterdam, The Netherlands, p. 245-252.

Terzaghi, K (1955) Evaluation of coefficients of subgrade reaction. Geotechnique, Vol. 5, No.4, p.297-326. 